African Crop Science Journal by African Crop Science Society is licensed under a Creative Commons Attribution 3.0 Uganda License. Based on a work at www.ajol.info/ and www.bioline.org.br/cs DOI: https://dx.doi.org/10.4314/acsj.v29i1.4

\title{
PROTOCOL OPTIMISATION FOR MICROPROPAGATION OF ETHIOPIAN
} YAM

\author{
D. BIRHAN ${ }^{1,2}$, D. OBSSI ${ }^{2}$ and K. MULUGETA ${ }^{1}$
}

${ }^{1}$ Adama Science and Technology University, School of Applied Natural Science Applied Biology Program, P. O. Box, 1888; Adama, Ethiopia

${ }^{2}$ Ethiopian Institute of Agricultural Research, National Agricultural Biotechnology Research Center, P. O. Box, 249, Holeta, Ethiopia

Corresponding author: dobssi@gmail.com

(Received 20 March 2020; accepted 19 January 2021)

\begin{abstract}
Yam (Dioscorea spp.) is a monocotyledonous tuber forming tropical vine, which belongs to the family Dioscoreaceae, and genus Dioscorea. Yam is well known for medicinal properties, as well as nutritional values. Conventional propagation of yam is limited by low propagation rates; hence, in vitro propagation provides the best alternative to overcome such limitations. The objective of this study was to optimise a protocol for in vitro micro-propagation of Ethiopian yam (D. alata, bulcha variety). Explants were obtained from young leaves of bulcha variety, and sterilised using different concentrations of $\mathrm{NaOCl}$, for different time exposures. Sodium hypochlorite $(1 \%)$ at 15 minutes exposure time, showed $100 \%$ survival of explants. The combination of $0.5 \mathrm{BAP}$ with $1 \mathrm{mgl}^{-1} \mathrm{NAA}$ was the best concentration for shoot induction. For shoot multiplication, BAP at $1.5 \mathrm{mg} \mathrm{l}^{-1}$ gave the highest shoots per explants $(7.28 \pm 0.07)$, with shoot length of $8.72 \pm 0.43 \mathrm{~cm}$. MS medium with $2.0 \mathrm{mg}$ $1^{-1} \mathrm{NAA}$ and $1.5 \mathrm{mg} \mathrm{l}^{-1} \mathrm{IBA}$ gave the highest rooting percentage and root number $(10.6 \pm 0.44)$, with a root length of $13.80 \pm 0.44$. In vitro acclimatised plantlets, which were transferred to a greenhouse for hardening, had $90 \%$ survival rate on soil medium. Thus, for micropropagation of bulcha yam variety, $\mathrm{MS}+1.5 \mathrm{mg} \mathrm{l}^{-1}$ and MS plus $2.0 \mathrm{mg} \mathrm{l}^{-1} \mathrm{NAA}+1.5 \mathrm{mg} \mathrm{l}^{-1} \mathrm{IBA}$ is the best phytohormonal combination for shoot multiplication and invitro rooting, respectively.
\end{abstract}

Key Words: Dioscorea, MS Medium, nodal vine

\section{RÉSUMÉ}

L'igname (Dioscorea spp.) est un tubercule monocotylédone qui forme la vigne tropicale, qui appartient à la famille des Dioscoreaceae et au genre des Dioscorea. L'igname est bien connue pour ses propriétés médicinales, ainsi que pour ses valeurs nutritionnelles. La propagation conventionnelle de l'igname est limitée par de faibles taux de propagation; par conséquent, la propagation in vitro offre la meilleure alternative pour surmonter ces limitations. L'objectif de cette étude était d'optimiser un protocole de micro-propagation in vitro de l'igname Ethiopienne (D. alata, variété bulcha). Des explants ont été 
obtenus à partir de jeunes feuilles de la variété bulcha et stérilisés en utilisant différentes concentrations de $\mathrm{NaOCl}$, pour des expositions temporelles différentes. L'hypochlorite de sodium (1\%) à un temps d'exposition de 15 minutes a montré une survie de $100 \%$ des explants. La combinaison de 0,5 BAP avec $1 \mathrm{mgl}^{-1}$ NAA s'est avéré être la meilleure concentration pour l'induction des pousses. Pour la multiplication des pousses, le BAP à $1,5 \mathrm{mg} \mathrm{l}^{-1}$ a donné les pousses les plus élevées par explants $(7,28$ $\pm 0,07$ ), avec une longueur de pousses de $8,72 \pm 0,43 \mathrm{~cm}$. Le milieu MS avec $2,0 \mathrm{mg} \mathrm{l}^{-1} \mathrm{NAA}$ et $1,5 \mathrm{mg}$ $1^{-1}$ IBA a donné le pourcentage d'enracinement et le nombre de racines les plus élevés $(10,6 \pm 0,44)$, avec une longueur de racine de 13,80 $\pm 0,44$. Les plantules acclimatées in vitro, qui ont été transférées dans une serre pour durcissement, avaient un taux de survie de $90 \%$ sur un milieu de sol. Ainsi, pour la micropropagation de la variété bulcha yam, MS +1,5 $\mathrm{mg} \mathrm{l}^{1-1} \mathrm{et}_{\mathrm{MS}}$ plus $2,0 \mathrm{mg} \mathrm{l}^{-1} \mathrm{NAA}+1,5 \mathrm{mg} \mathrm{l}^{-1} \mathrm{IBA}$ est la meilleure combinaison phytohormonale pour la multiplication des pousses et l'enracinement in vitro, respectivement.

Mots Clés: Dioscorea, Milieu MS, vigne nodale

\section{INTRODUCTION}

Yam (Dioscorea spp.) is a monocotyledonous tuber, which belongs to the order Liliflorae, family Dioscoreaceae, and genus Dioscorea (Course, 1976).There are about 600 species of Dioscorea, among which white yam (Dioscorea rotundata), water yam (Dioscorea alata), aerial yam (Dioscorea bulbifera), yellow yam (Dioscorea cayenensis), trifoliate yam (Dioscorea dumentorum) and Chinese yam (Dioscoreae sculenta) are economically the most important species (Onwueme, 1978).It is reported that Ethiopia is partly the centre of origin for one of Dioscorea species ( $D$. abyssinica) (Zeven and Wet, 1982; Edossa, 1996).

Even though yam is an important contributor to food security and hunger reduction in developing countries, its production has been characterised by fluctuation since 2007 (Okwu et al., 2006; FAO,2012; Price et al., 2016). This is mainly beccause propagation of this species of yam by seeds, using conventional methods, is slow and inadequate for rapid multiplication (Nweke et al., 1991). Therefore, there is need to develop in vitro propagation methods for application in the production of plant materials (Vaillant et al., 2005; Abraham, 2009). Arditti (2009) contended that in vitro propagation methods provide large scale proliferation of high quality planting materials. It offers many advantages over conventional methods, like mass propagation; and produces pathogen free planting materials (Obssi et al., 2015).

Studies have been reported on some economically important Dioscorea species and landraces using nodal segments explants, with limited auxin and cytokinin types, concentrations and combinations (Jova et al.,2011; Das et al., 2013; Obsi et al., 2015; Sangar et al.2018; Hussein et al., 2018). Moreover, each variety requires its own regeneration protocol (Gonzalez et al., 1999). Therefore, the objective of this study was to develop an optimised protocol for in vitro micro-propagation of Ethiiopian yam.

\section{MATERIALS AND METHODS}

Plant materials. The material used in this study was the popular variety of yam (Dioscorea alata), variety bulcha, which was released by Bako Agricultural Research Centre in 2012. This variety shows superior performance, particularly in terms of productivity and tolerance to disease across the year; and out-yields (46.6 tonnes per hectare) other yam varieties on farmers' fields (Bikela et al., 2015). Mature Dioscorea tubers were obtained from Hawasa Agricultural Research Centre, located in regional state of Southern Nations and Nationalities.

About 20-60 grammes per piece of a nondormant tuber, containing periderm and some 
cortex parenchyma, was use (Aighewi et al., 2014). The piecies were grown in plastic pots filled with sterilised soil (Fig. 1) for two months, to be used as mother plant. The host Plant Tissue Culture Laboratory maintained an average temperature of $25 \pm 2{ }^{\circ} \mathrm{C}$. The tuber sets in pots were watered with distilled water, twice a week and allowed to grow for about two months when buds sproutted. Two months later, the apex was differentiated into stems of approximately 10-16 nodes. The Plants were staked with sticks and one node size explants were cut from stems for sterilisation.
Stock solution preparation. Murashige and Skoog (MS) basal medium was used throughout this study. Initially, full strength stock solutions of macronutrients, micronutrients and vitamins plus other organic supplements were separately prepared (Murashige and Skoog, 1962). To do so, appropriate amounts of each nutrient were dissolved in double distilled water, consecutively in such a way that the next nutrient was added after the first one was completely dissolved. After all the components were completely dissolved using a magnetic stirrer, the solution was poured into plastic
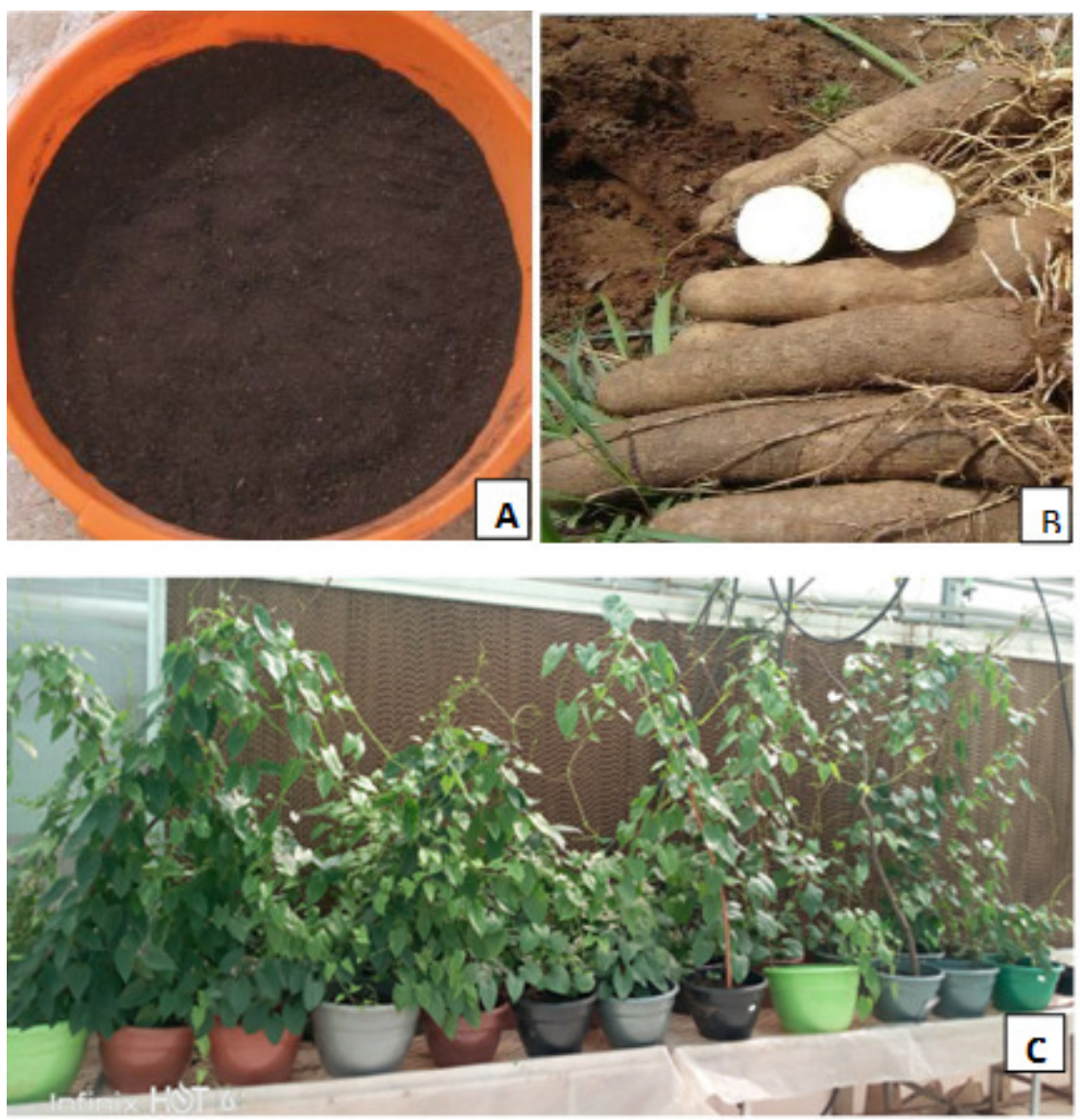

Figure 1. Plant material source and mother stock establishment in a green house: (A), plastic pots already filled with sterilised soil; (B), tubers and fragments of tuber; (C), Mother Stock plant under greenhouse condition. 
bottles and stored at $+4{ }^{\circ} \mathrm{C}$ until it was used, for a maximum of four weeks.

Plant growth regulators stock solution. Plant growth regulators, namly 6-Benzyl Amino-purine (BAP), Indol-Butyric Acid (IBA) and Naphthalene Acetic Acid (NAA) were used in this study. All of the plant growth regulators stock solutions were prepared by dissolving the powder in 2-3 drops of $\mathrm{NaOH}$ based on the requirement of the plant growth regulators. Then, the volume was adjusted by adding double distilled water at a ratio of $1: 1(1 \mathrm{mg}$ $\mathrm{ml}^{-1}$ ); and stirred using magnetic stirrer. Upon complete dissolution, the solution of each PGR was poured into labeled $50 \mathrm{ml}$ plastic bottles and stored in a refrigerator at $+4{ }^{\circ} \mathrm{C}$ for short term use.

Culture medium preparation. MS nutrient medium with its full macro- and micronurients, vitamins and iron source was used to prepare the stock solution. Each component was added into one litre beaker and $30 \mathrm{~g} \mathrm{l}^{-1}$ of sucrose and $1 \mathrm{~g} \mathrm{l}^{-1}$ activated charcoal were dissolved in double distilled water in all cases. The shoot initiation medium containing different concentrations of BAP $(0.25,0.5$, 0.75 and $\left.1 \mathrm{mg} \mathrm{l}^{-1}\right)$ and different concentrations of NAA $\left(0.5,1\right.$ and $\left.1.5 \mathrm{mg}^{-1}\right)$ in combination, were used. The shoot multiplication medium prepared using different concentrations of BAP $\left(0.5,1.0,1.5,2.0\right.$ and $\left.2.5 \mathrm{mg} \mathrm{l}^{-1}\right)$, was also used. On the other hand, the rooting media containing IBA $\left(0.5,1.0,1.5\right.$ and $\left.2 \mathrm{mg} \mathrm{l}^{-1}\right)$ in combination with NAA $(0.5,1.0,1.5,2$ and $2.5 \mathrm{mg} \mathrm{l}^{-1}$ ) was used in full MS medium.

After the appropriate amount of medium component was added and stirred using a magnetic stirrer, the volume was adjusted to full level using double distilled water. The $\mathrm{pH}$ of the medium was adjusted with $\mathrm{HCl}$ and $\mathrm{NaOH}$ solution, before $2.3 \mathrm{~g} \mathrm{l}^{-1}$ agar powder was added. Then, the gently mixed medium was boiled in a microwave oven $\left(85^{\circ} \mathrm{C}\right)$, until the agar was melted. Then, $30 \mathrm{ml}$ of the prepared medium was dispensed into culture jars, which were covered with caps immediately after dispensing the medium. They were then autoclaved at a temperature of 121 ${ }^{\circ} \mathrm{C}$ and pressure of $105 \mathrm{KPa}$ for 15 minutes. After autoclaving, the medium was kept in the culture room until use.

Experiments and their designs. A total of four expirements were conducted (Effective sterilisation of explants using $\mathrm{NaOCl}$, effects of BAP in combination with NAA for shoot induction, Effect of different concentrations of BAP on shoot multiplications and effect of NAA and IBA combinations on in vitro rooting). All experiments were laid in a completely randomised design (CRD), in factorial treatment combinations, five replications per treatment and three explants per jar under each replicate.

Before laying out the multiplication and rooting experiments, sufficient explants were multiplied, until the desired numbers of explants were obtained. Explants were cultured on a PGR-free medium, before their use to avoid carry-over effects from the previous culture media. Controls were set for each experiment with zero concentration of growth regulators.

Explants preparation. Nodal segments collected from actively growing shoots from 1-2 months old established mother plant in a greenhouse, were used as a sources of explants. Nodal vine cuttings of $6-10 \mathrm{~cm}$ were washed with a detergent solution (liquid soap) and rinsed several times with running tap water. Then, the nodal vine cuttings/explants were transferred to the laminar flow hood cabinet, and surface sterilised in $70 \%$ ethanol for 3 minutes. Thereafter, the treated explants were rinsed four times with sterilised distilled water and surface sterilised using $0.5,1$ and $1.5 \%$ of sodium hypo-chlorite $(\mathrm{NaOCl})$ disinfectant solutions, plus a few drops of tween-20 (2-3 drops) for varying exposure times $(5,10$ and 15 minutes).

The nodal cut vines were transferred into double distilled water and washed several times (at least 3 changes) till all traces of the sterilant 
were washed off; and then soaked with sterile blotting paper. Sterilised nodal explants were further reduced to $1 \mathrm{~cm}$ size by removing all the dead and affected tissue prior to culture. All steps were performed in a laminar flow cabinet to maintain aseptic condition. Three explants were cultured per glass jar with five replicates.

Initiation and culturing of explants. Aseptic nodal cultures were transferred onto MS media, fortified with different concentrations of BAP in combination with NAA for two weeks to determine best medium for shoot induction. The media used contained macro- and micro-nutrient salts according to Murashige and Skoog. In addition, NAA (0.5, 1 and $\left.1.5 \mathrm{mg}^{-1}\right)$ in $3 \times 4$ combination with $\operatorname{BAP}\left(0.25,0.5,0.75\right.$ and $\left.1 \mathrm{mg}^{-1}\right)$, were added to the MS medium with $1 \mathrm{~g}^{-1}$ activated charcoal (AC). The sterilised explants which were dissected and reduced into $1 \mathrm{~cm}$ single nodal segments were implanted onto the Murashige and Skoogs agar gelled medium. It was then sealed, labeled and kept inside the growth room with 16 hours photoperiod (8 hours dark) and 2500 lux light intensity from cool white florescent 60 watt bulbs, at average temperature of $25 \pm 2{ }^{\circ} \mathrm{C}$. The growth of the nodal cultures were observed daily. The subculture was done on the $15^{\text {th }}$ days of culture. Data on explants showing shoot initiation were collected after two weeks of culture.

BAP and shoot multiplication. Bud initiation was enhanced by the addition of BAP and NAA. After bud initiation, for further growth, cultured plants were transferred to the media, supplemented with five concentrations of BAP $\left(0.5,1.0,1.5,2.0\right.$ and $\left.2.5 \mathrm{mg} \mathrm{l}^{-1}\right)$ to investigate its effect on shoot multiplication. The mean of shoot length, shoot number and leaf number were recorded after 30 days of culture.

NAA and IBA combinations on in vitro rooting. The effect of two auxin types and their concentrations on rooting of in vitro shoots were studied using MS medium, supplemented with five concentrations of NAA $\left(0.5,1,1.5,2\right.$ and $\left.2.5 \mathrm{mg} \mathrm{l}^{-1}\right)$ and four concentration of IBA $\left(0.5,1,1.5\right.$ and $\left.2 \mathrm{mg} \mathrm{l}^{-1}\right)$ in $5 \times 4$ combination was tested with $1 \mathrm{~g} \mathrm{l}^{-1}$ AC. Root number and root length were determined after 40 days of culture.

Acclimatisation. For acclimatisation, plantlets of about $50 \mathrm{~mm}$ tall and 4 to 5 leaves; and well-developed root systems were washed with tap water to remove adhering media and agar on the roots of plantlets. Rooted micropropagates were transplanted into plastic pots filled with top soil, sand soil and compost in the ratio of $1: 2: 1$.

The plastic pots were placed in a greenhouse where pot trays were covered with a white plastic bag to maintain uniform humidity. The plantlets were transferred to greenhouse for gradual acclimatisation until they established themselves in the soil. After 10 days, the transparent plastic bags were removed, and the data on survival were recorded.

Data analysis. Data collected were analysed using Analysis of Variance of SAS software version 9.3. The Least Significance Difference (LSD) was used for mean separation at $\mathrm{P}<$ 0.05 .

\section{RESULTS AND DISCUSSION}

Effective sterilisation of explants using NaOCl. Surface sterilisation with $1 \%$ of $\mathrm{NaOCl}$ for 15 minutes caused minimal contamination; while the same reagent caused maximum survival response in vitro cultures . The percentages of contamination and survival rates in cultures were recorded as, 0 and $100 \%$, respectively. After 7 days of culture, $0 \%$ tissue death was recorded with unaffected growth rate, when explants were sterilised for 15 minutes with increased concentration of $\mathrm{NaOCl}(1.5 \%)$, high efficiency of sterilisation was achieved, but there were negative effects on survival rate, as well as on growth and development of explants. Sodium hypochlorite 
treatment for 10 minutes at $1 \%$ was also an effective surface steriliser, with $86.66 \%$ survival rate and $60.00 \%$ of contamination (Table 1). The contamination was dramatically decreased as the exposure time increased within the same level of sodium hypochlorite solution (Table 1). Disinfection with $1.5 \%$ sodium hypochlorite solution for 15 minute also resulted in the least contamination $(0 \%)$ and highest clean explants (100\%), but no live tissues.

Comparing the interaction effect posed by the chemical and the duration of disinfection against the aim of sterilisation, disinfection of Bulch variety with $1 \%$ sodium hypochlorite solution, for 15 minutes was the most effective sterilisation treatment. This resulted in the highest survival (100\%) without any contamination.

The increase of sodium hypochlorite concentration with long exposure time, showed a negative effect on plantlets, resulting in brownish colour with a lower survival rate $(0 \%)$. The occurrence of high contamination rate of the culture at a relatively lower concentration and shorter exposure time treatment combinations was possibly due to the insufficiency of sterilant concentration and exposure duration to remove or kill the contaminant agents mainly fungi and bacteria.

From the present study, $1 \%$ sodium hypochlorite in combination with about 2-3 drops of tween-20 for 15 minutes, is the best of all sterilisation regimes tested, with the lowest contamination and highest survival response of the variety. $\mathrm{NaOCl}$ is believed to be a very effective sterilising agent and is used frequently for surface sterilisation of plants for in vitro culture (Talei et al., 2011). These results are confirmatory with earlier works (Oyebanji et al., 2009), which reported sodium hypochlorite as a good sterilising agents for many others plants.

Other studies reported that ethanol and $\mathrm{NaOCl}$ were good sterilising agents for the plant-like peach, soft rush, oil palm, and other plants (Ogero et al., 2012). Alam et al. (2016) further reported that the requirements for sterilisation are different and depend on the tissues and the type of the explants used for micropropagation. Many sterilisation procedures based on sodium hypochlorite solution and $70 \%$ ethanol rinse are usually considered good sterilising procedures for the

TABLE 1. Interaction effect of sodium hypochlorite concentrations and time of exposure on sterilisation of Dioscorea species (Dioscorea alata)

\begin{tabular}{lcccc}
\hline $\begin{array}{l}\text { Sodium hypochlorite } \\
\text { concentration (\%) }\end{array}$ & $\begin{array}{c}\text { Time of exposure } \\
\text { (minute) }\end{array}$ & $\begin{array}{c}\text { Contamination } \\
(\%)\end{array}$ & $\begin{array}{c}\text { Clean culture } \\
(\%)\end{array}$ & $\begin{array}{c}\text { Tissue survival } \\
\text { rate }(\%)\end{array}$ \\
\hline 0.5 & 5 & $100^{\mathrm{a}}$ & $0^{\mathrm{h}}$ & $0^{\mathrm{h}}$ \\
0.5 & 10 & $93.33^{\mathrm{b}}$ & $6.67^{\mathrm{g}}$ & $13.33^{\mathrm{g}}$ \\
0.5 & 15 & $86.66^{\mathrm{c}}$ & $13.34^{\mathrm{f}}$ & $26.66^{\mathrm{f}}$ \\
1 & 5 & $80^{\mathrm{d}}$ & $20^{\mathrm{e}}$ & $53.33^{\mathrm{c}}$ \\
1 & 10 & $60^{\mathrm{e}}$ & $40^{\mathrm{d}}$ & $86.66^{\mathrm{b}}$ \\
1 & 15 & $0^{\mathrm{h}}$ & $100^{\mathrm{a}}$ & $100^{\mathrm{a}}$ \\
1.5 & 5 & $13.33^{\mathrm{f}}$ & $86.67^{\mathrm{c}}$ & $46.66^{\mathrm{d}}$ \\
1.5 & 10 & $6.66^{\mathrm{g}}$ & $93.34^{\mathrm{b}}$ & $33.33^{\mathrm{e}}$ \\
1.5 & 15 & $0^{\mathrm{h}}$ & $100^{\mathrm{a}}$ & $0^{\mathrm{h}}$ \\
$\mathrm{CV}$ & & & & \\
\hline
\end{tabular}

Means with the same letter in the same column are not significantly different, $\mathrm{CV}=\mathrm{Coefficient}$ of Variation 
in vitro culture of many plants (Aasim et al., 2013).

Shoot initiation. There was a highly significant interaction effect $(\mathrm{P}<0.0001)$ of BAP and NAA (BAP*NAA) on rate of shoot induction (Table 2). The basal medium (control) failed to stimulate bud break response in the cultured explants, even when the cultures were maintained further than the normal observation period. BAP at $0.5 \mathrm{mg} \mathrm{l}^{-1}$ combined with $1 \mathrm{mg} \mathrm{l}^{-1}$ NAA resulted in the highest response in which an average of 100 $\%$ ex plant response with a mean shoot length of $4.42 \pm 0.02 \mathrm{~cm}$ was obtained (Table 2, Fig. 2).

The second best shoot induction of $86 \%$ was obtained in the MS medium supplemented with $0.25 \mathrm{mg} \mathrm{l}^{-1} \mathrm{BAP}$, combined with $1 \mathrm{mg} \mathrm{l}^{-1}$ NAA; with a mean shoot length of $3.55 \pm 0.04$ $\mathrm{cm}$ (Table 2, Fig. 2). Among all the treatments, the minimum rate of shoot induction $(20 \%)$ was observed on MS containing $1 \mathrm{mg} \mathrm{l}^{-1} \mathrm{BAP}$, combined with $1.5 \mathrm{mg} \mathrm{l}^{-1} \mathrm{NAA}$. In this case, the percent of shoot induction was significantly lower than that of the first two combinations of plant growth regulators.

Shoot bud development capacity of nodal cultures increased with increase in concentrations of both NAA and BAP from zero to 1 and $0.5 \mathrm{mg} \mathrm{l}^{-1}$, respectively; and reduced with further addition of both hormones (Table 2). This result conforms to the report of Fotso et al. (2013) who considered $0.5 \mathrm{mg} \mathrm{l}^{-1}$ of BAP together with $1.0 \mathrm{mg} \mathrm{l}^{-1}$ of NAA as the best-supplemented medium for nodal cuttings derived shoot regeneration. A similar result has also been recently reported in the case of micropropagation of other Discorea species like Dioscorea composita (Alizadeh et al., 1998), Dioscorea floribunda (Borthakur and Singh, 2002), Dioscorea batatas (Koda and Kikuta, 1991) and Dioscorea abyssinica (Mar-tine and

TABLE 2. Effects of BAP and NAA on in vitro shoot induction rate of Dioscorea species (Dioscorea alata), from nodal explants culture on MS

\begin{tabular}{|c|c|c|c|}
\hline \multicolumn{2}{|c|}{ Plant growth regulators $\left(\mathrm{mg} \mathrm{l}^{-1}\right)$} & \multirow[t]{2}{*}{ Shoot induction $(\%)$} & \multirow[t]{2}{*}{ Shoot length $(\mathrm{cm})$} \\
\hline $\operatorname{BAP}\left(\mathrm{mg} \mathrm{l}^{-1}\right)$ & $\mathrm{NAA}\left(\mathrm{mg} \mathrm{l}^{-1}\right)$ & & \\
\hline 0 & 0 & $0.00^{1}$ & $0.00 \pm 0.34 \mathrm{j}$ \\
\hline 0.25 & 0.5 & $26.66^{j}$ & $0.97 \pm 0.01^{\mathrm{hi}}$ \\
\hline 0.25 & 1 & $86^{\mathrm{b}}$ & $3.55 \pm 0.04^{\mathrm{b}}$ \\
\hline 0.25 & 1.5 & $53^{\mathrm{f}}$ & $1.46 \pm 0.03^{\mathrm{e}}$ \\
\hline 0.5 & 0.5 & $59.99^{e}$ & $1.74 \pm 0.01^{\mathrm{d}}$ \\
\hline 0.5 & 1 & $100^{\mathrm{a}}$ & $4.42 \pm 0.02^{\mathrm{a}}$ \\
\hline 0.5 & 1.5 & $32.66^{\mathrm{i}}$ & $1.12 \pm 0.19^{\mathrm{gh}}$ \\
\hline 0.75 & 0.5 & $46^{\mathrm{g}}$ & $1.36 \pm 0.40^{\text {ef }}$ \\
\hline 0.75 & 1 & $73^{c}$ & $2.91 \pm 0.02^{c}$ \\
\hline 0.75 & 1.5 & $40^{\mathrm{h}}$ & $1.27 \pm 0.00^{\mathrm{fg}}$ \\
\hline 1 & 0.5 & $33.33^{\mathrm{i}}$ & $1.15 \pm 0.02^{\mathrm{g}}$ \\
\hline 1 & 1 & $66.66^{\mathrm{d}}$ & $1.84 \pm 0.03^{\mathrm{d}}$ \\
\hline 1 & 1.5 & $20^{k}$ & $0.9 \pm 0.06^{\mathrm{i}}$ \\
\hline $\mathrm{CV}$ & & 7.29 & 6.94 \\
\hline
\end{tabular}

$\mathrm{BAP}=$ Benzyl Amino Purine. NAA = Naphthalene Acetic Acid, Means with the same letter in the same column are not significantly different, $\mathrm{CV}=$ Coefficient of variation 

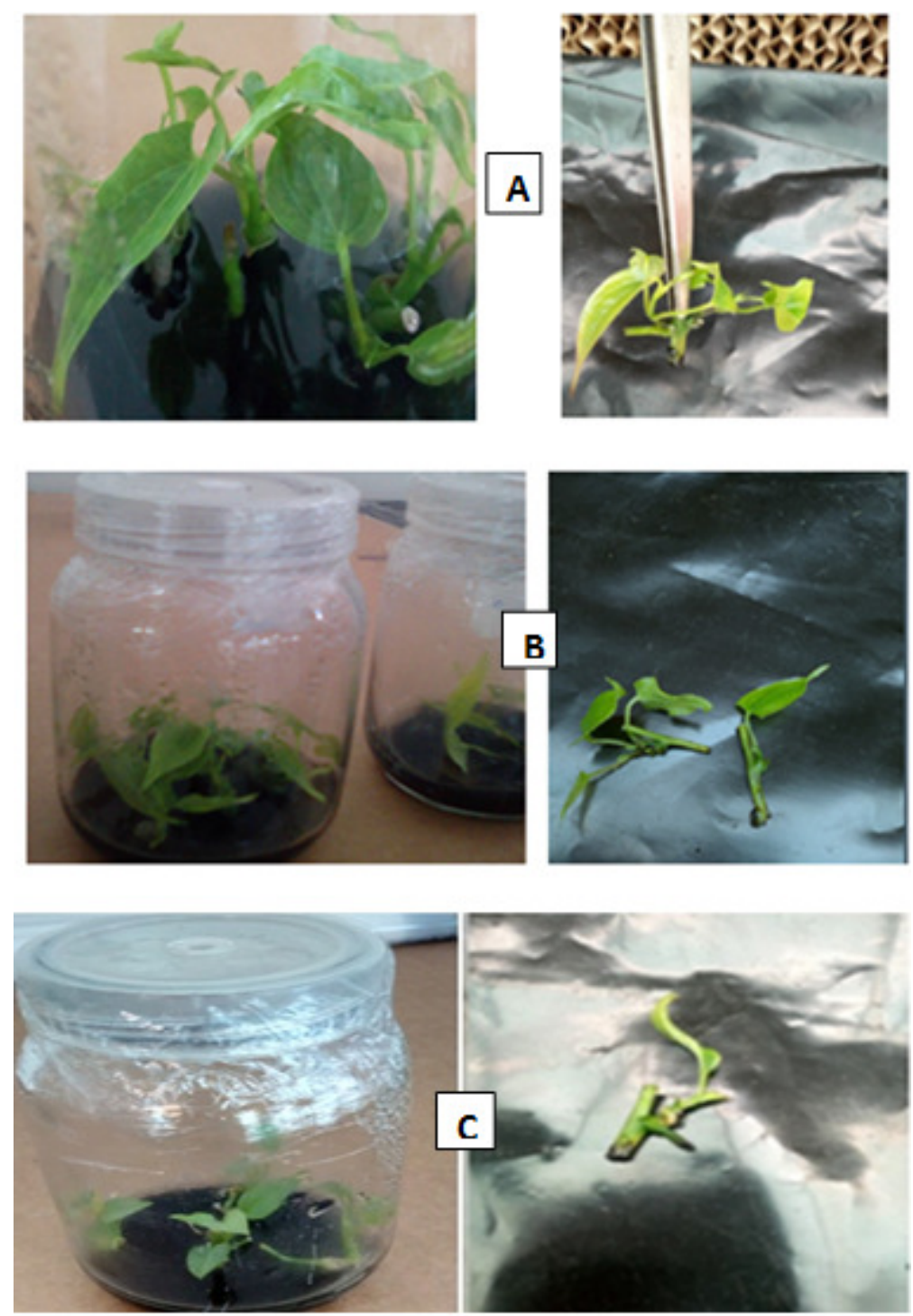

Figure 2. Response of Nodal explants of Dioscorea alata on initiation medium with different combinations of BAP and NAA. MS medium with $0.5 \mathrm{mg} \mathrm{l}$-BAP and $1 \mathrm{mg} \mathrm{l}^{-} \mathrm{NAA}$ (A), MS medium with $0.25 \mathrm{mg} \mathrm{l}^{-} \mathrm{BAP}$ and $1 \mathrm{mg} \mathrm{l}^{-} \mathrm{NAA}(\mathrm{B}), \mathrm{MS}$ medium with $1 \mathrm{mg} \mathrm{l}^{-} \mathrm{BAP}$ and $1.5 \mathrm{mg} \mathrm{l}^{-} \mathrm{NAA}(\mathrm{C})$.

Cappadocia, 1991). Therefore, BAP (a cytokinin) with NAA (auxin) were good hormone combination for shoot intiation of Ethiopian yam, Bulcha variety.

In the presnt study, cultured nodal explants of Dioscorea spp. in solid MS medium started to develop micro-leaves after two week of culturing, with varying growth responses for the initiation medium, cultured nodal segments to all of the culture media compositions; except the control (without plant growth regulators) (Table 2). The combination of $0.5 \mathrm{mg} \mathrm{l}^{-1} \mathrm{BAP}$ and $1 \mathrm{mg} \mathrm{l}^{-1}$ NAA produced the highest shoot bud induction. George et al. (2008) similarly reported that, for shoot initiation cytokinins act best when combined with auxins.

BAP and shoot multiplications. The effect of different concentrations of BAP on shoot multiplication of Ethiopian yam is shown in 
Table 3. Increasing BAP from 0.5 to $1.00 \mathrm{mg}$ $\mathrm{I}^{-1}$ presented a significant increase from $4.54 \pm 0.2$ to $6.3 \pm 0.45$ shoots per explant, from $4.06 \pm 0.26$ to $6.12 \pm 0.52 \mathrm{~cm}$ shoot length and from $3.38 \pm 0.18$ to $5.01 \pm 0.35$ leaves per shoot (Table 3). MS media, supplemented with BAP $\left(1.5 \mathrm{mg} \mathrm{l}^{-1}\right)$, induced maximum number of shoots per explants $(7.28 \pm 0.07)$ with highest shoot length of $8.72 \pm 0.43 \mathrm{~cm}$ and number of leaf (Table 3, Fig. 3). MS media with $1 \mathrm{mg}$ $1^{-1} \mathrm{BAP}$ gave the second highest shoot number $(6.3 \pm 0.45)$ with shoot length $6.12 \pm 0.52 \mathrm{~cm}$ and highest leaf number $5.01 \pm 0.35$.

The present results were in line with the finding of several other reports (Poornima and Ravishankar, 2007; Chu et al., 2002, Mahesh et al. 2010) whereby the nature and amount of the cytokinin significantly determined growth of various genotypes of Dioscorea spp. Manoharan et al. (2016), on the other hand obtained MS media with $0.4 \mathrm{mg} \mathrm{l}^{-1} \mathrm{BAP}$ as the optimum concentration for shoot proliferation. According to Gopitha et al. (2010), low concentrations of cytokinin promote shoot multiplication and elongation. The difference might be due to the difference in type of media and yam variety.

The minimum shoot number $(2.12 \pm 0.08)$ with minimum shoot length $(1.97 \pm 0.12)$, and minimum leaf number $(2.51 \pm 0.35)$ were recorded on MS media with $2.5 \mathrm{mg} \mathrm{l}^{-1}$ BAP (maximum concentration) (Table 3, Fig. 3). Increasing BAP above $1.5 \mathrm{mg} \mathrm{l}^{-1}$, resulted in shoots with stunted features, which were generally unusable. These effects were attributed to high dosage of hormone that disorderd the metabolism of the shoots and inhibited cell division and multiplication (Gopitha et al., 2010). This is agrement with the work of Hussein et al. ( 2018) where increasing or decreasing of the BAP concentration from $1.50 \mathrm{mg} \mathrm{l}^{-1}$ led to decline in the growth parameters like leaf number, shoot height and shoot number.

\section{NAA and IBA combinations on in vitro} rooting. The rooting responses of shoots on different media showed high significant differences $(\mathrm{P}<0.0001)$ due to the interaction of the phytohormones applied and for number of roots and root length over a period of four weeks (Fig. 4, Table 4). Rooting was better in the culture which had a combination of $2 \mathrm{mg}$ $\mathrm{l}^{-1} \mathrm{NAA}$ with $1.5 \mathrm{mg} \mathrm{l}^{-1} \mathrm{IBA}$; where 10.6 \pm 0.44 root number with an average number of $13.80 \pm 0.44 \mathrm{~cm}$ root length per plantlets were recorded (Fig. 4). The second highest performer in rooting was the combination of $1 \mathrm{mg} \mathrm{l}^{-1}$ of IBA and $2 \mathrm{mg} \mathrm{l}^{-1}$ of NAA; where $8.67 \pm 1.13$ number of roots and shoots

TABLE 3. Shoot multiplication in nodal explants of Dioscorea species (Dioscorea alata) cultured on semisolid MS medium supplemented with various concentration of BAP

\begin{tabular}{lccc}
\hline BAP $\left(\mathrm{mg} \mathrm{l}^{-1}\right)$ & Number of leaves & Number of shoot & Shoot height $(\mathrm{cm})$ \\
\hline 0 & $2.09 \pm 0.09^{\mathrm{f}}$ & $3.05 \pm 0.37^{\mathrm{e}}$ & $2.53 \pm 0.14^{\mathrm{e}}$ \\
0.5 & $3.38 \pm 0.18^{\mathrm{d}}$ & $4.54 \pm 0.28^{\mathrm{c}}$ & $4.06 \pm 0.26^{\mathrm{c}}$ \\
1 & $5.01 \pm 0.35^{\mathrm{b}}$ & $6.3 \pm 0.45^{\mathrm{b}}$ & $6.12 \pm 0.52^{\mathrm{b}}$ \\
1.5 & $7.12 \pm 0.22^{\mathrm{a}}$ & $7.28 \pm 0.07^{\mathrm{a}}$ & $8.72 \pm 0.43^{\mathrm{a}}$ \\
2 & $4.40 \pm 0.19^{\mathrm{c}}$ & $3.64 \pm 0.25^{\mathrm{d}}$ & $3.44 \pm 0.44^{\mathrm{d}}$ \\
2.5 & $2.51 \pm 0.35^{\mathrm{e}}$ & $2.12 \pm 0.08^{\mathrm{f}}$ & $1.97 \pm 0.12^{\mathrm{f}}$ \\
$\mathrm{CV}$ & 5.90 & 6.65 & 7.80 \\
\hline
\end{tabular}

BAP $=$ Benzyl Amino Purine. Means with the same letter in the same column are not significantly different, $\mathrm{CV}=$ Coefficient of variation 

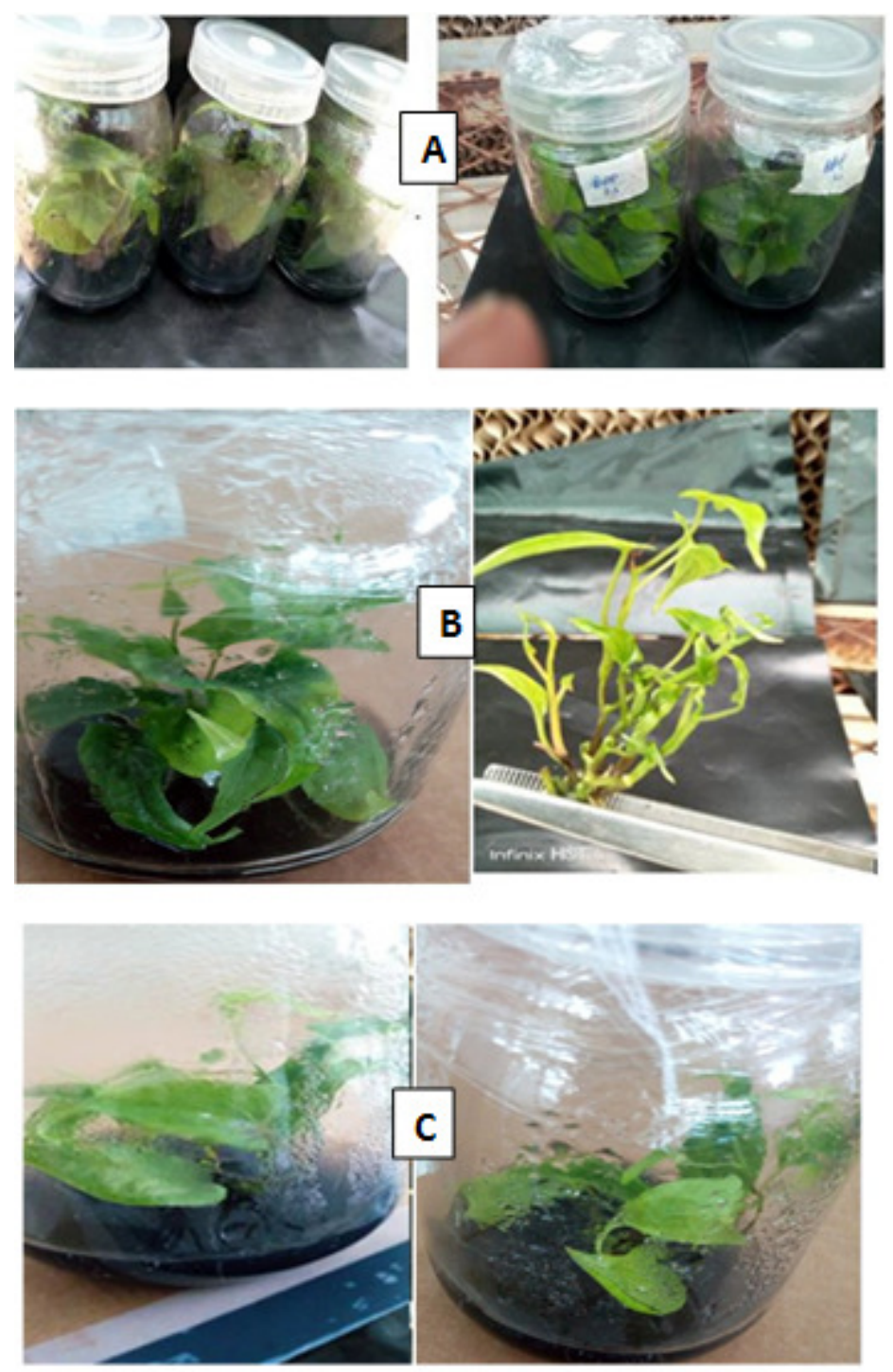

Figure 3. Effect of BAP on shoot multiplication, MS medium with $1.5 \mathrm{mg}$ l-BAP(A), MS medium with $1 \mathrm{mg}^{-1} \mathrm{BAP}(\mathrm{B}), \mathrm{MS}$ medium with $2.5 \mathrm{mg}^{-1} \mathrm{BAP}(\mathrm{C})$.

responded with $11.50 \pm 0.21 \mathrm{~cm}$ average root length per plantlet. However, increasing the concentrations of IBA and NAA from (1.5 and $2 \mathrm{mgl}^{-1}$, respectively) decreased the percentage of rooted shoots continsistently; but required only short days for root initiation.

Rooting at lower levels of NAA and IBA $\left(0.5 \mathrm{mg}^{-1}\right)$ showed semi-elongated and minimum root number, with minimum root length with poor root growth and with dwarf growth of shoots in the cultured shoots during the four weeks of observation period. Shoot planted on auxin free medium developed very small amounts of roots $(1.00 \pm 0.01)$ with minimum average root length $(1.00 \pm 0.029 \mathrm{~cm}$ (Fig. 4). The well rooted plantlets were successfully acclimatised and cultivated in green house. About $90 \%$ of plantlets were survived and established as health plant (Fig. 5).

The production of plantlets with abundant rooting in vitro is very important for the 

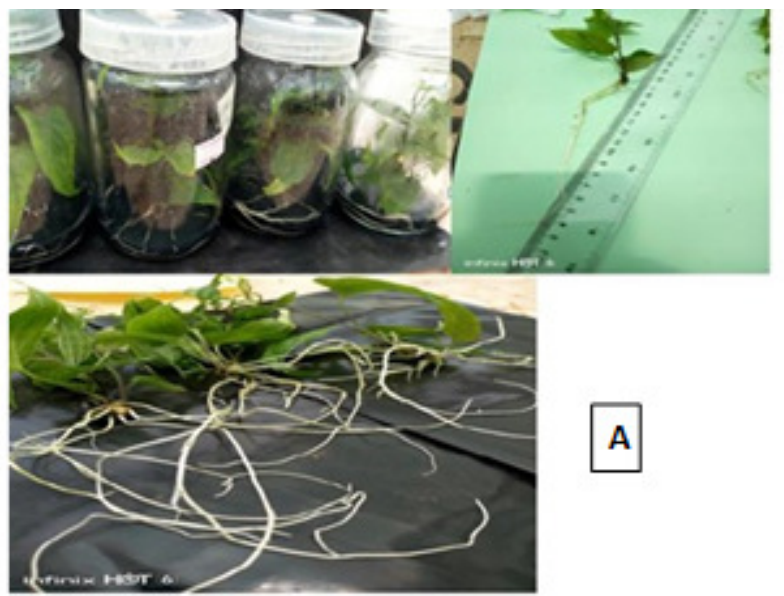

\section{A}
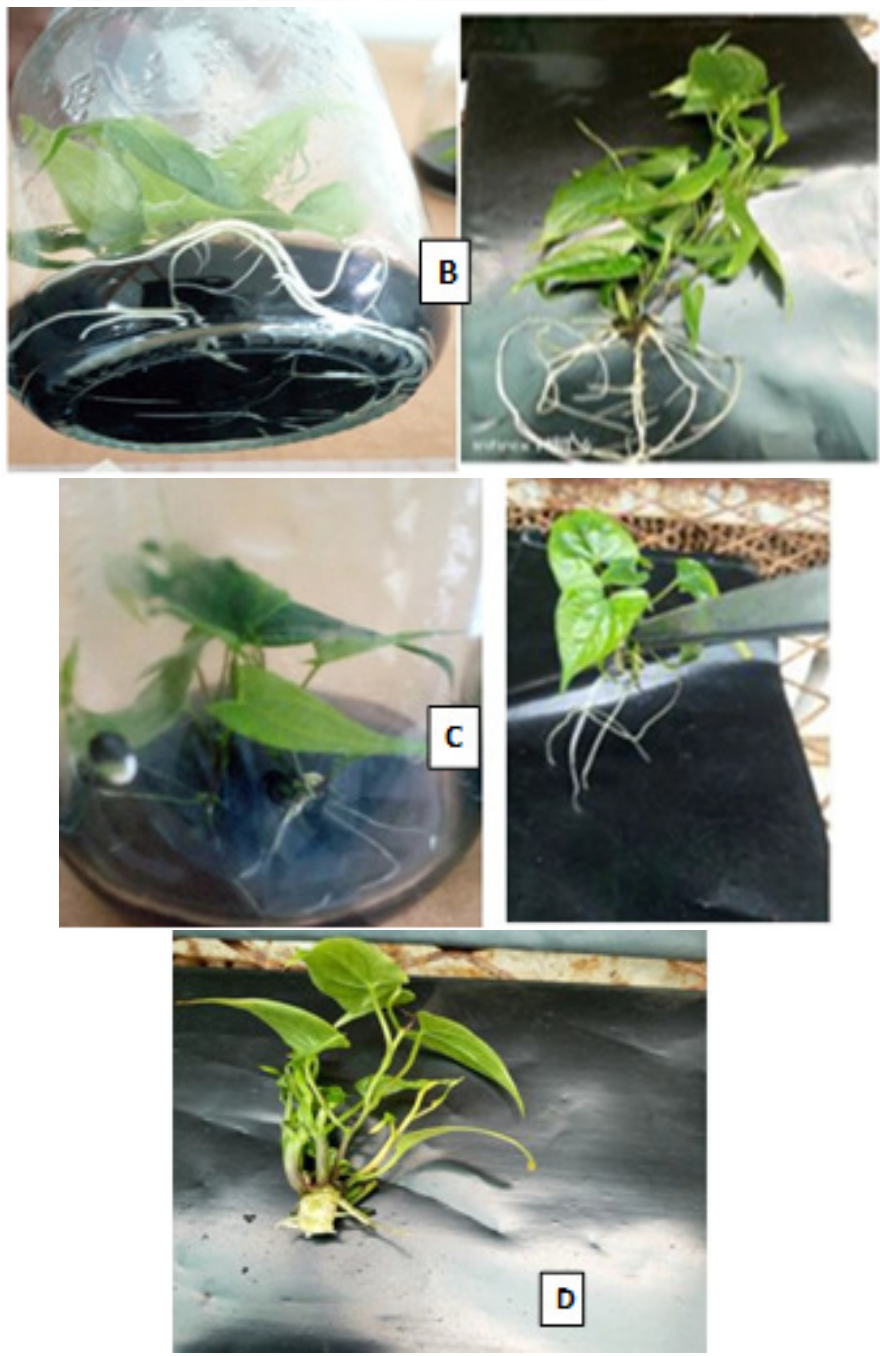

Figure 4. In vitro rooting of Dioscorea alata shoots on full strength MS medium containing combination of NAA and IBA. Root induction on $2 \mathrm{mg} \mathrm{l}^{-1} \mathrm{NAA}$ with $1.5 \mathrm{mg} \mathrm{l}^{-1} \mathrm{IBA}$ (A), Root induction on $2 \mathrm{mg} \mathrm{l}^{-1} \mathrm{NAA}$ with $1 \mathrm{mg} \mathrm{l}^{-1} \mathrm{IBA}(\mathrm{B})$, Root induction on $0.5 \mathrm{mg} \mathrm{l}^{-1} \mathrm{NAA}$ w. 
TABLE 4. Influence of different combination of NAA and IBA on rooting of in vitro generated shoot lets of Dioscorea species (Dioscorea alata)

\begin{tabular}{|c|c|c|c|}
\hline $\mathrm{NAA}\left(\mathrm{mg} \mathrm{l}^{-1}\right)$ & $\operatorname{IBA}\left(\mathrm{mg} \mathrm{l}^{-1}\right)$ & Root height (cm) & Root number \\
\hline 0 & 0 & $1.00 \pm 0.01^{\circ}$ & $1.00 \pm 0.2^{p}$ \\
\hline 0.5 & 0.5 & $1.04 \pm 0.21_{\mathrm{o}}$ & $1.4 \pm 0.31^{\mathrm{op}}$ \\
\hline 0.5 & 1 & $2.70 \pm 0.68^{\mathrm{km}}$ & $3.24 \pm 0.43^{\mathrm{m}}$ \\
\hline 0.5 & 1.5 & $3.56 \pm 0.38^{1}$ & $4 \pm 0.22^{\mathrm{kl}}$ \\
\hline 0.5 & 2 & $3.22 \pm 0.40^{\mathrm{Im}}$ & $3.64 \pm 0.03^{\mathrm{Im}}$ \\
\hline 1 & 0.5 & $4.90 \pm 0.54^{\mathrm{ij}}$ & $4.6 \pm 0.06^{\mathrm{j}}$ \\
\hline 1 & 1 & $5.38 \pm 0.05^{\mathrm{hi}}$ & $4.76 \pm 0.06^{\mathrm{ij}}$ \\
\hline 1 & 1.5 & $7.49 \pm 0.34^{\mathrm{e}}$ & $6.94 \pm 0.22^{\mathrm{d}}$ \\
\hline 1 & 2 & $6.50 \pm 0.18^{f}$ & $5.52 \pm 1.7^{\mathrm{gh}}$ \\
\hline 1.5 & 0.5 & $6.95 \pm 0.03^{\mathrm{f}}$ & $6.7 \pm 0.22^{\mathrm{de}}$ \\
\hline 1.5 & 1 & $8.07 \pm 0.74^{\mathrm{d}}$ & $7.68 \pm 0.23^{c}$ \\
\hline 1.5 & 1.5 & $9.11 \pm 0.11^{\mathrm{c}}$ & $8.19 \pm 0.54^{\mathrm{cb}}$ \\
\hline 1.5 & 2 & $6.95 \pm 0.02^{\mathrm{f}}$ & $6.2 \pm 0.23^{\mathrm{ef}}$ \\
\hline 2 & 0.5 & $6.50 \pm 0.15^{\mathrm{f}}$ & $5.94 \pm 0.04^{\mathrm{fg}}$ \\
\hline 2 & 1 & $11.50 \pm 0.21^{\mathrm{b}}$ & $8.67 \pm 1.13^{b}$ \\
\hline 2 & 1.5 & $13.80 \pm 0.44^{\mathrm{a}}$ & $10.6 \pm 0.44^{\mathrm{a}}$ \\
\hline 2 & 2 & $5.94 \pm 0.04^{\mathrm{g}}$ & $5.26 \pm 0.32^{\mathrm{hi}}$ \\
\hline 2.5 & 0.5 & $4.50 \pm 0.41^{\mathrm{j}}$ & $4.26 \pm 0.18^{\mathrm{jk}}$ \\
\hline 2.5 & 1 & $3.04 \pm 0.69^{\mathrm{Im}}$ & $3.39 \pm 0.23^{\mathrm{m}}$ \\
\hline 2.5 & 1.5 & $1.94 \pm 0.30^{n}$ & $2.6 \pm 0.35^{\mathrm{n}}$ \\
\hline 25 & 2 & $1.46 \pm 0.10^{n}$ & $1.6 \pm 0.54^{0}$ \\
\hline $\mathrm{CV}$ & & 9.19 & 7.60 \\
\hline
\end{tabular}

IBA = Indol-3-Butyric Acid, NAA= Naphthalene Acetic Acid. Means with the same letter in the same column are not significantly different, $\mathrm{CV}=$ Coefficient of Variation

successful establishment of regenerated plantlets in soil (Kumar and Nair, 1979). Behera et al. (2008) used $2 \mathrm{mg} \mathrm{l}^{-1} \mathrm{NAA}$ and $2 \mathrm{mg} \mathrm{l}^{-1}$ IBA in half-strength MS medium for different species of Dioscorea and induced the highest rooting. Earlier authors also obtained similar findings that combinations of auxin NAA and IBA were needed for better production of roots in Dioscorea prazeri (Thankappan and Patell, 2011), Dioscorea nipponica (Chen et al., 2007), Dioscorea esculenta (Belarmino and Rosario,1991), (Obssi et al., 2015), Dioscorea rotundata (Taha and Abdelaziz, 2017) and yam landreses (Hussein et al., 2018). But Bahar et al. (2010) suggested that NAA or IBA alone used to profuse rooting on Dioscorea oppositifolial and reported that NAA was more effective than IBA. Additionally, these results could be explained on the basis that auxininduced responses which involved cell division, cell enlargement, protein and nucleic acids synthesis that increase the apical dominance, growth and elongation (Wilkins, 1989). On the other hand, Forsyth and Stadan (1981) reported that rooting relies on MS media with $5 \mathrm{mg} \mathrm{l}^{-1}$ IBA and a results of Mao et al. (1995) showed that higher concentrations of NAA, IBA or IAA induced root growth rather than the lower concentrations. 

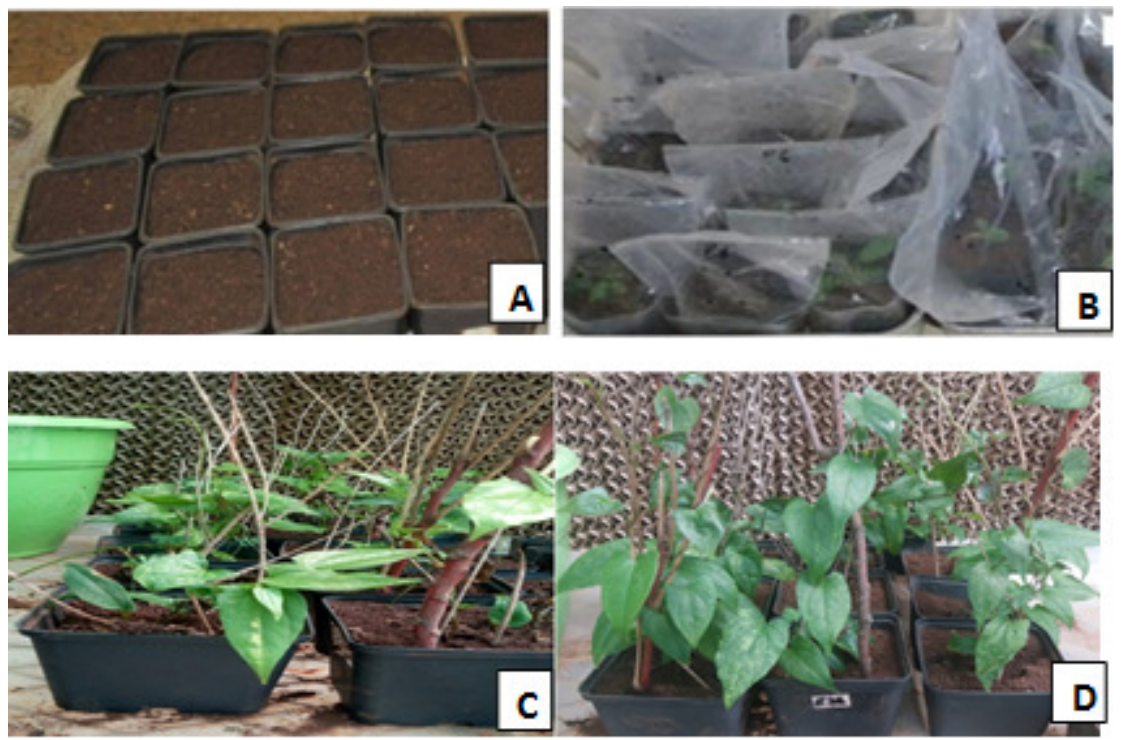

Figure 5. Acclimatisation in greenhouse: (A) plastic pots filled with sterilised soil, (B) first week of acclimatisation (as covered), (C) 15 days after covering plastic bag has been removed, (D) 30 days after covering plastic bag has been removed.

\section{CONCLUSION}

The maximum of shoot induction (100\%) was observed on MS medium supplemented with $0.5 \mathrm{mg} \mathrm{l}^{-1}$ of BAP and $1 \mathrm{mg} \mathrm{l}^{-1}$ of NAA. MS medium containing $1.5 \mathrm{mg} \mathrm{l}^{-1}$ of BAP also produced the highest shoot number. Best rooting percentage was achieved on full strength MS basal media containing $1.5 \mathrm{mg} \mathrm{l}^{-}$ ${ }^{1}$ of IBA in combination with $2.0 \mathrm{mg} \mathrm{l}^{-1}$ of NAA followed by MS basal media containing 2.0 mg ${ }^{-1}$ of NAA and $1 \mathrm{mg}^{-1}$ IBA which resulted $8.67 \pm 0.13$ root number, and $11.50 \pm 0.21 \mathrm{~cm}$ root length.

\section{ACKNOWLEDGEMENT}

The authors acknowledge Ethiopian Institute of Agricultural Research National Agricultural Biotechnology Research Centre and Adama Science and Technology University (ASATU) School of Applied Natural Science Applied Biology Programme, for supporting and financing this research.

\section{REFERENCES}

Aighewi, B.A. 1998. Seed yam (Dioscorea rotundata Poir.) production and quality in selected yam zones of Nigeria. Ph.D. thesis, University of Ibadan, Ibadan, Nigeria. 252pp.

Arditti, J. 2009. History of orchid propagation: a mirror of the history of biotechnology. Plant Biotechnology Reports 3:1-56.

Behera K. K, Sahoo S. and Prusti A. 2009.Regeneration of plantlet of water yam (Dioscorea oppositifolia L.) through in vitro culture of nodal segments. Notulae Botanicae Horti Agrobotanici Cluj 37:94102.

Behera, K.K., Sahoo, S. and Prusti, A.B. 2008. Effect of plant growth regulator on invitromicropropagation of Bitter Yam (Dioscorea hispida Dennst.). International Journal of Integrative Biology 4(1):50-54.

Behera, K.K., Sahoo, S.S. and Prusti, A. 2010. Micropropagation of greater yam (Dioscoreaalata L. cv. Hatikhujia) through 
vine nodes. Journal of Root Crops 36(1):27-32.

Borthakur, M. and Singh, R.S. 2002. Direct plantlet regeneration from male inflorescences of medicinal yam (Dioscorea floribunda Mart. \& Gal.). In Vitro Cellular \& Developmental Biology. Plant 38:183-185.

Chu, E.P. and Ribeiro, R.D.F. 2002. Growth and carbohydrate changes in shoot cultures of Dioscorea species as influenced by photoperiod, exogenous sucrose and cytokinin concentrations. Plant Cell, Tissue and Organ Culture 70(3):241-249.

Coursey, D.G. 1976. Yams, Dioscorea spp. (Dioscoreaceae). In: Simmonds, E.D. (Ed.). Evolution of crop plants. Longman, London. pp. 70-74.

Dukan, S., Belkin, S. and Touati, D. 1999. Reactive oxygen species are partially involved in the bactericidal action of hypochlorous acid. Archives of Biochemistry and Biophysics 367:311-316.

Edossa, E.1996. Root and tuber crops potential as food crops in the humid areas of Ethiopia. Newsletter of Agricultural Research 11:9-11.

Edossa Etissa. 1998. Yams: Exploration, collection and evaluation.

FAO. 2012. Food and Agricultural Organization of the United Nations Production Year.

Fay, M.F.1992. Conservation of rare and endangered plants using in vitro methods. In Vitro, Cellula \& Developmental Biology-Plant 28(1):1-4.

Forsyth, C. and Van Staden, J. 1981. An Improved Method of in vitro Propagation of Dioscoreabulbifera. Plant Cell, Tissue and Organ Culture 1(1):275-281.

George, E.F., Hall, M.A. and De Clerk, G.J. 2008. Plant propagation by Tissue culture. Volume 1, Springer, Dordrecht.

Gopitha, K., Bhavani, L. and Senthilmanickam, J. 2010. Effect of the different auxins and cytokinins in callu induction shoot root regeneration in sugarcane. International Journal of Pharma and Bio Sciences 1(3).
Hussein, I., Mengs, B. and Matiwos. T. 2019. In vitro protocol optimization for micro propagation of yam landraces (Dioscorea species) using nodal culture. International Journal of Pharmaceutical Science and Research 4(3):31-38.

Ibadan Saleil, V., Degras, L. and Jonard R. 1990. Obtention des plantesindemnes du virus de la mosaïque de l'igname (YMV) par culture in vitro des apex chez l'ignameaméricaine Dioscorea trifida L. Elsevier/INRA 10:605-615.

Jova, M.C., Kosky, R.G. and Cuellar, E.E. 2011. Effect of liquid media culture systemson yam plant growth (Dioscorea alata L.'PacalaDuclos'). Biotechnology, Agronomy, Society and Environment 15:515-521.

Kumar, C.R.M. and Nair, G.M. 1979. Notes on the effects of planting material and levels of farmyard manure on the yield of D.alata. Journal of Root Crop 5:67-68.

Mahesh, R., Muthuchelian, K. and Maridass, Raju G. 2010. In vitro propagation of wild yam, Dioscorea wightii through nodal cultures. International Journal of Biological Technology 1:111-113.

Mantell, S.H. and Hugo, S.A. 1989. Effects of photoperiod,mineral medium strength, inorganic ammonium, sucrose and cytokininon root, shoot and microtuberdevelopmentin shoot cultures of Dioscorea alataL. and D. bulbifera $\mathrm{L}$. Plant Cell Tissue Organ Culture 16:23-37.

Manoharan, R., Tripathi, J.N. and Tripathi, L. 2016. Plant regeneration from axillary budderived callus in white yam (Dioscorea rotundata). Plant Cell, Tissue and Organ Culture (PCTOC) 126(3):481-497.

Mao, A.H., Wetten, A., Fay, M. and Caligari, P.D.S. 1995. In vitro propagation of Clerodendrumcolebrookianum Walp, a potential natural antihypertension medicinal plant. Plant Cell Reports 14:493-496.

Martine, J. and Cappadocia, M. 1991 .In vitro tuberization in Dioscorea alata L. 'Brazo fuerte' and 'Florido' and D.abyssinica 
Hoch. Plant Cell Tissue Organ Culture 26:147-152.

Murashige, T. and Skoog, F. 1962. A revised medium for rapid growth and bioassays with tobacco tissue cultures. Physiologia Plantarum 15:473-479.

Nweke, F.I., Ugwu, B.O., Asadu, C.L.A. and Ay, P. 1991. Production cost in the yam based cropping systems of southeastern Nigeria. RCPM Research Monograph No. 6. International Institute of Tropical Agriculture, Ibadan, Nigeria. 29pp.

Obssi, D., Bantte, K. and Diro, M. 2015. Effect of different combinations of plant growth regulators on in vitro propagation of yam (Dioscorea species). Journal of Applied Biotechnology 3(2):20.

Ogero, O., Mburugu, G., Mwangi, M., Ngugi, M. and Ombori,O. 2012. Low cost tissue culture technology in the regeneration of sweet potato (Ipomoea batatas L). Research Journal of Biology 2(2):51-58.

Okwu, D.E. and Ndu, C.U. 2006. Evaluation of the phytonutrients, mineral and vitamin contents of some varieties of yam (Dioscorea spp). International Journal of Molecular and Advanced Sciences 2(2):199-203.

Onwueme, I.C. 1978. The tropical root crops: Yams, cassava, sweet potato and cocoyams. Chichester: John Wiley and Sons Ltd.

Oyebanji, O.B., Nweke, O., Odebunmi, O., Galadima, N.B., Idris, M.S. and Nnodi, U.N. 2009. Plymouth Student Scientist 4: 432-449.

Poornima, G.N. and Ravishankar, R.V. 2007. In vitro propagation of wild yams (Dioscorea oppositifolia (Linn) and
(Dioscorea pentaphylla (Linn). African Journal of Biotechnology 6(20).

Price, E.J., Wilkin, P., Sarasan, V. and Fraser, P.D. 2016. Metabolite profling of Dioscorea (yam) species reveals under-utilized biodiversity and renewable sources for high-value compounds. Scientific reports 6:29136, Doi: 10.1038/srep29136.rica. YIIFSWA Working Paper No. 3. IITA,

Taha, S.S. and. Abdelaziz, M.E. 2017. .In vitro propagation of yam via nodal segment culture. Bioscience Research 14(4):12171222.

Talei, D., Saad, M.S., Yusop, M.K., Mihdzar, A.K. and Valdiani, A. 2011. Effect of different surface sterilizers on seed germination and con-tamination of King of Bitters (Andrographispaniculata Nees). American Eurasian Journal of Agriculture and Environmental Sciences 10:639-643.

Vaillant, V., Bade, P. and Constant, C. 2005. Photoperiod affects the growth and development of yam plantlets obtained by in vitro propagation. Biologiaplantarum 49(3):355-359.

Wilkins, M.B. 1989. Advanced plant physiology. The Bath Press, Avon. pp. 1315.

Yan, H., Yang, L,. Yangrui Li. 2011. Improved growth and quality of Dioscorea fordii Prainet Burk and Dioscorea alata plantlets using temporary immersion system. African Journal of Biotechnology 10: 19444-19448.

Zeven, A.C. and De Wet, J.M.J. 1982. Dictionary of cultivated plants and their regions of diversity. Center for Agricultural Publishing and Documentation, Wageningen, The Netherlands. 